\title{
Tinjauan Maqasid al-Syari'ah Terhadap Penetapan Permohonan Wali Adhal di Pengadilan Agama Lamongan (Studi Terhadap Penetapan No. 0073/Pdt.P/2008/Pa.Lmg.)
}

\author{
Ulfiyatul Fauziyah, Ihda Shofiyatun Nisa', Yuli Roisotul A. \\ UIN Maulana Malik Ibrahim Malang, Institut Agama Islam Nahdlatul Ulama \\ Tuban \\ E-mail: ulfifauziah8@gmail.com, ihdashofiya95@gmail.com, \\ yulirois271@gmail.com
}

\begin{abstract}
Abstrak: Kesesuaian dasar dan pertimbangan hakim dalam memberikan penetapan mengenai adhalnya wali dengan kemaslahatan yang ditimbulkan. Dalam perkara No.: 0073/Pdt.P/2008/PA.Lmg., wali pemohon keberatan menikahkan anak perempuannya dengan tidak menyertakan alasan yang jelas dan sesuai syar'i. Hal ini tidak dibenarkan menurut peraturan hukum yang berlaku karena merupakan perbuatan yang dzalim. Adanya penolakan dari wali pemohon, maka dikhawatirkan akan terjadi hal-hal yang bertentangan dengan syari'at Islam, misalnya terjadinya hamil di luar nikah atau kawin lari. Oleh karena itu, pernikahan antara pemohon dan calon suami pemohon lebih mendatangkan maslahah. Jenis penelitian yang digunakan dalam penelitian ini adalah penelitian kepustakaan (library research). Penelitian ini menggunakan analisis kualitatif yang bersifat deskriptik-analitik serta menggunakan pendekatan normatif-empiris. Hasil penelitian ini adalah; Pertimbangan hakim menurut maqasid al-syari'ah yaitu permohonan penetapan wali adhal termasuk hifzh al-din dan hifzh al-nasl, sedangkan pertimbangan hakim menurut hukum positif bahwa ayah pemohon tidak suka dengan calon suami pemohon terdapat dalam Pasal 18 ayat (4) Peraturan Menteri Agama RI Nomor 11 Tahun 2007 dan dalam Pasal 19 Kompilasi Hukum Islam disebutkan bahwa wali nikah merupakan rukun yang harus dipenuhi bagi calon mempelai wanita, karena tidak sah menikah tanpa wali. Walaupun seorang wali mempunyai hak untuk memilihkan calon suami bagi anaknya, wali dilarang mempersulit perkawinan wanita yang berada dalam perwaliannya selama mendapatkan calon yang sekufu. Apabila seorang wali menolak untuk menikahkan wanita yang berada dalam perwaliannya, maka disebut sebagai wali adhal (keberatan).

Kata kunci: Maqasid al-Syari'ah, wali adhal, Pengadilan Agama Lamongan.
\end{abstract}




\section{Pendahuluan}

Islam memandang perkawinan sebagai suatu cita-cita yang sangat ideal. Perkawinan bukan hanya sebagai persatuan antara laki-laki dan perempuan, bahkan lebih dari itu, perkawinan sebagai kontrak sosial dengan seluruh aneka ragam tugas dan tanggung jawab keduanya. Dalam Al-Qur'an dengan jelas telah disebutkan bahwa tujuan dari perkawinan adalah untuk membangun kehidupan yang aman, tentram dan damai, dengan penuh cinta dan kasih sayang didalamnya. ${ }^{1}$ Para mujtahid sepakat bahwa nikah adalah suatu ikatan yang dianjurkan syariat. Setiap Muslim yang sudah berkeinginan untuk nikah dan khawatir terjerumus ke dalam perbuatan zina maka dianjurkan untuk melaksanakan nikah. Perihal demikian, menurut kesepakatan para imam madzhab merupakan ibadah yang lebih utama daripada haji, shalat, jihad dan puasa sunnah.

Pernikahan dapat dilaksanakan dengan beberapa syarat dan rukun yang telah ditetapkan, salah satu diantaranya adalah keharusan adanya wali bagi calon istri, yaitu ayah kandungnya sendiri atau bila sudah meninggal (atau tidak ada dikarenakan suatu hal atas ketiadaannya) maka dapat digantikan oleh urutan wali sebagaimana yang dicantumkan dalam kitab-kitab fiqih maupun KHI (Kompilasi Hukum Islam).

Menurut pendapat Imam Al-Syafi'i dan Imam Hambali yakni Pernikahan tidak sah kecuali ada wali laki-laki. Oleh karena itu, jika seorang perempuan mengakadkan dirinya sendiri untuk menikah maka pernikahannya tidak sah. Sedangkan Hanafi berpendapat bahwa Perempuan boleh menikahkan dirinya sendiri dan boleh pula mewakilkan kepada orang lain untuk menikahkan dirinya jika ia telah dibolehkan menggunakan hartanya dan juga tidak boleh ia dihalang-halangi kecuali jika menikah dengan orang yang tidak sekufu' dengannya. Jika demikian, maka walinya boleh menghalangi pernikahannya.

Adapun pendapat Imam Maliki, jika perempuan itu mempunyai kemuliaan (bangsawan) dan cantik serta digemari orang maka pernikahannya tidak sah, kecuali ada wali. Sedangkan jika keadaannya tidak demikian maka ia boleh dinikahi orang lain yang bukan kerabat dengan kerelaan dirinya. Imam Dawud Al-Dhabiri berpendapat: Jika perempuan tersebut seorang gadis maka pernikahannya tidak sah tanpa wali. Sedangkan jika perempuan itu seorang janda maka sah pernikahannya meskipun tanpa wali. Imam Abu Tsawr dan Imam Abu

${ }^{1}$ Q.S. Ar-Rum (30) : 21. 
Yusuf mengatakan, sah pernikahan perempuan tersebut asalkan mendapat izin dari walinya. Akan tetapi, jika ia menikah tanpa izin dari walinya, lalu keduanya mengadukan pernikahan itu kepada hakim yang bermazhab Imam Hanafi, dan hakim menetapkan sahnya pernikahan tersebut, maka hakim yang bermazhab Imam Al-Syafi'i tidak boleh membatalkannya, kecuali menurut pendapat Imam Abu Sa'id alIsthakhri. $^{2}$

Hukum Islam adalah hukum yang bersumber dari wahyu Allah yang diperuntukkan bagi umat manusia. Namun demikian, sebagian besar masalah-masalah hukum dalam Islam, oleh Allah hanya diberikan dasardasar atau prinsip-prinsip dalam Al-Qur'an. Bertitik tolak dari dasar atau prinsip ini, dituangkan pula oleh Nabi penjelasan melalui hadis-hadisnya. Di dalam Al-Qur'an tidak disebutkan dengan jelas tentang wali adhal, akan tetapi keharusan adanya wali ditafsirkan dari Q.S. Al-Baqarah ayat 232; yang artinya:

"Apabila kamu menalak istri-istrimu, lalu habis idahnya, maka janganlah kamu (para wali) menghalangi mereka kawin lagi dengan bakal suaminya, apabila telah terdapat kerelaan di antara mereka dengan cara yang makruf. Itulah yang dinasehatkan kepada orangorang yang beriman di antara kamu kepada Allah dan hari kemudian. Itu lebih baik bagimu dan lebih suci. Allah mengetahui, sedang kamu tidak mengetahui. ${ }^{3}$

Ayat di atas mengandung pengertian akan keharusan adanya wali dalam pernikahan, wali dilarang menghalangi perkawinan wanita yang ada di bawah perwaliannya selama ia mendapat pasangan yang sekufu'. Maksud sekufu' di sini adalah bahwa antara pihak laki-laki dan wanita harus seimbang baik agama, nasab, pendidikan, dan lain sebagainya.

Adapun ukuran kafa'ah dalam Al-Qur'an dan hadits tidak memberikan batasan yang pasti. Para Imam Madzhab menetapkan ukuran dan norma kafa' ah yaitu:

1. Imam Syafi'i, Imam Hanafi dan Imam Hambali sepakat bahwa, kafa'ah itu ada lima hal yaitu : agama, nasab, merdeka, kekayaan dan keahlian. Tetapi mereka berbeda pendapat dalam hal harta dan kelapangan hidup. Imam Hanafi dan Imam Hambali menganggapnya sebagai syarat, tetapi Imam Syafi'i tidak.

2 Syaikh al-'Allamah Muhammad bin 'Abdurrahman ad-Dimasyqi, Fiqih Empat Mazhab,(Bandung. Hasyimi, 2015), hlm. 318-319

${ }^{3}$ Q.S. Al-Baqarah, 232. 
2. Sedangkan Imamiyah dan Imam Maliki tidak memandang keharusan adanya kafa'ah kecuali dalam hal agama. ${ }^{4}$

Ukuran dan norma di atas masih dipegang oleh beberapa wali dalam menikahkan anak gadisnya. Namun di lain pihak, anak juga sudah mempunyai pilihan sendiri untuk pendamping hidupnya. Ketika perbedaan keinginan antara orang tua dan anak terjadi dan tidak tercapai adanya kesepakatan, tidak jarang menyebabkan perselisihan antara anak dan orang tua, sehingga menyebabkan terjadi wali keberatan atau tidak mau menikahkan atau memberi izin pernikahan anak gadisnya.

Pada masa sekarang ini, masih ada wali nasab yang menolak bertindak menjadi wali, padahal keinginan seorang anak untuk menikah dengan laki-laki yang dicintainya sangat kuat, terlebih lagi jika laki-laki tersebut sudah sekufu', sepadan dan sanggup membayar mahar.

Dalam Islam tidak ada salahnya jika orang tua menolak calon yang diajukan anaknya, apabila calon tersebut tidak memenuhi kafa'ah yang ditentukan dalam hukum Islam. Namun, dalam kenyataannya masih ada orang tua atau wali yang menolak menikahkan tanpa alasan yang dibenarkan menurut agama Islam.

Dalam perkawinan tidak selamanya dapat dilaksanakan dengan mulus (tanpa adanya halangan), terkadang ayah sebagai wali enggan menikahkan anaknya dengan berbagai alasan, diantaranya tidak setuju dengan calon suami atau ada alasan lain yang menjadikan orang tua enggan menjadi wali. Keengganan wali untuk menikahkan anaknya disebut adhal. Apabila terjadi keengganan menjadi wali maka calon istri dapat mengajukan permohonan wali aḍhal ke Pengadilan Agama setempat supaya Pengadilan Agama menetapkan ke-aḍhalan wali dan memerintahkan kepada KUA setempat untuk menyediakan wali hakim dan menikahkan. Pindahnya perwalian dari wali nasab kepada wali hakim bila seluruh wali tidak ada dalam keadaan enggan mengawinkan, dasarnya adalah hadis yang diriwayatkan oleh Ibn Majah dari 'Aisyah, dengan Yang dimaksud potongan hadits di atas yakni jika wali-walinya berselisih, maka penguasa (hakimlah) yang menjadi walinya.

Wali adalah salah satu dari rukun nikah yang harus ada untuk sahnya sebuah perkawinan. Oleh karena itu, seorang wanita tidak bisa menikahkan dirinya sendiri tanpa didampingi wali yang sah. Wali

4 Muhammad Jawad Mughniyah, "Fiqh Lima Mdzhab, Ja'fari, Hanafi, Maliki, Syafi'i, Hambali", (Jakarta : Lentera, 1996), hlm. 350. 
ditunjuk berdasarkan skala prioritas secara tertib, dimulai dari orang yang paling berhak, yaitu mereka yang paling akrab, lebih kuat hubungan darahnya. Menurut jumhur Ulama, wali yang lebih berperan adalah wali nasab yang diambil dari garis ayah.

Maqashid al-syari'ah tujuan syari'at merupakan kajian yang awalnya menjadi suplemen dalam ilmu ushul fiqh, sejalan dengan waktu, para ulama yang berkonsentrasi di bidang ushul fiqh dan fiqh kontemporer menitik beratkan perhatiannya pada maqashid al-syari'ah. Kajian maqashid al-syari'ah di anggap penting karena dapat menjadi landasan penetapan hukum pertimbangan ini menjadi suatu keharusan bagi masalah-masalah yang tidak ditemukan ketegasannya dalam nas. Dalam melakukan ijtihad, seorang mujtahid harus menguasai aspek maqashid alsyari'ah seorang tidak akan bisa memahami dengan benar ketentuan syara' jika tidak mengetahui tujuan hukum dan mengetahui kasus-kasus yang berkaitan dengan ayat yang diturunkan.

Perlu diketahui bahwa syariah tidak menciptakan hukum-hukumnya dengan kebetulan, tetapi dengan hukum-hukum itu bertujuan untuk mewujudkan maksud-maksud yang umum. Kita tidak dapat memahami nash-nash yang hakiki kecuali mengetahui apa yang dimaksud oleh syara' dalam menciptakan nash-nash itu. Petunjuk-petunjuk lafadz dan ibaratnya terhadap makna sebenarnya, kadang-kadang menerima beberapa makna yang ditarjihkan yang salah satu maknanya adalah mengetahui maksud syara'.

Kaidah-kaidah pembentukan hukum Islam ini, oleh ulama ushul diambil berdasarkan penelitian terhadap hukum-hukum syara', illatillatnya dan hikmah (filsafat) pembentukannya diantara nash-nash itu pula ada yang menetapkan dasar-dasar pembentukan hukum secara umum, dan pokok-pokok pembentukannya secara keseluruhan seperti juga halnya wajib memelihara dasar-dasar dan pokok-pokok itu dalam mengistimbath hukum dari nash-nashnya, maka wajib pula memelihara dasar-dasar dan pokok-pokok itu dalam hal yang tidak ada nashnya, supaya pembentukan hukum itu dapat merealisasikan apa yang menjadi tujuan pembentukan hukum itu, dan dapat mengantarkan kepada merealisasikan kemaslahatan manusia serta menegakkan keadilan diantara mereka. ${ }^{5}$

Contoh pada kasus perkara Nomor : 0073/Pdt.P/2008/PA.Lmg. yang

${ }^{5}$ Hasbi Umar, Nalar Fiqih Kontemporer, ( Jakarta, Gaung Persada Press, 2007), hlm. 120 
telah diputus oleh Majelis Hakim pada tanggal 30 Desember 2008. Pemohon berumur 21 tahun dan berstatus perawan yang berkeinginan menikah dengan laki-laki yang menjadi pilihannya. Dalam pertimbangannya berdasarkan pemeriksaan identitas ternyata pemohon bertempat tinggal di wilayah hukum Pengadilan Agama Lamongan.

Alasan pemohon dalam mengajukan permohonan wali adhal adalah karena ayah pemohon bertindak sebagai wali dari pemohon tidak bersedia menjadi wali atas rencana pernikahan pemohon dengan laki-laki yang di pilihnya dengan alasan yang tidak jelas. Pemohon telah berusaha mendaftarkan rencana pernikahan tersebut di Kantor Urusan Agama. namun ditolak karena keberatannya ayah pemohon tesebut.

Permohonan pemohon agar ditetapkan adhalnya wali untuk melangsungkan pernikahan dengan wali hakim karena wali pemohon tidak bersedia menjadi wali nikah bagi pemohon. Maka dengan memperhatikan ketentuan Pasal 18 ayat (5) Peraturan Menteri Agama RI Nomor 11 tahun 2007 jo. Dengan perlu dibuktikan terlebih dahulu tentang adhalnya wali. ${ }^{6}$

Dalam amar putusan disebutkan, bahwa berdasarkan pertimbanganpertimbangan hakim, diantaranya berupa keterangan pemohon yang dikuatkan dengan keterangan saksi-saksi di muka persidangan. Majelis Hakim berpendapat bahwa antara pemohon dan calon suami pemohon telah sekufu' dan tidak ada hubungan yang menghalangi pernikahan mereka, serta berdasarkan ketentuan Pasal 23 ayat (2) Kompilasi Hukum Islam dan sesuai ketentuan Pasal 18 ayat (4) Peraturan Menteri Agama RI Nomor 11 tahun 2007 tersebut, maka Majelis Hakim mengabulkan permohonan pemohon, menetapkan bahwa wali pemohon adalah adhal, menetapkan dan menunjuk Kepala Kantor Urusan Agama Kecamatan Mantup Kabupaten Lamongan untuk menikahkan pemohon dengan wali hakim, dan membebankan pemohon untuk membayar seluruh biaya perkara sebesar Rp. 191.000,- (seratus sembilan puluh satu ribu rupiah). ${ }^{7}$

Dalam perkara ini pertimbangan hukum yang diambil oleh Majelis Hakim Pengadilan Agama Lamongan adalah bahwa wali pemohon telah menolak menikahkan anak perempuannya dengan alasan ayah pemohon

${ }^{6}$ Penetapan Pengadilan Agama Lamongan Perkara Permohonan Wali Adhal nomor: 0073/Pdt.P/2008/PA.Lmg., hlm 5.

${ }^{7}$ Penetapan Pengadilan Agama Lamongan Perkara Wali Adhal Nomor: 0073/Pdt.P/2008/PA.Lmg., hlm. 6 
mempunyai pilihan lain, padahal antara pemohon dengan calon suaminya telah sama-sama berumur dewasa yang dalam hal ini sudah bisa menentukan pilihan hidupnya sendiri tanpa lagi bergantung kepada orang tua. Oleh sebab itu wali disini tidak mempunyai hak untuk menghalangi pemohon melangsungkan pernikahan dengan laki-laki pilihannya. Karena, seorang wali diperbolehkan memaksa anaknya untuk menikah dengan pilihannya, bukan pilihan anaknya disebut sebagai wali mujbir. Hal itu dikhususkan bagi orang yang kehilangan kemampuannya, seperti orang gila, anak-anak yang masih belum mencapai umur tamyiz boleh dilakukan wali mujbir atas dirinya. Sebagaimana dengan orangorang yang kurang kemampuannya, seperti anak-anak dan orang yang akalnya belum sempurna, tetapi belum tamyiz (abnormal).

Pada penetapan permohonan wali adhal di Pengadilan Agama Lamongan Nomor : 0073/Pdt.P/2008/PA.Lmg. di atas, karena dalam perkara ini wali pemohon keberatan menikahkan anak perempuannya dengan tidak menyertakan alasan yang jelas dan sesuai syar'i, dan ini tidak dibenarkan menurut peraturan hukum yang berlaku karena merupakan perbuatan yang dzalim.

Karena hal tersebut, maka peneliti tertarik untuk melakukan peneltian terhadap kasus diatas. Dengan tujuan ingin mengetahui apa sebenarnya yang menjadi pertimbangan hakim dalam penetapan permohonan wali adhal jika dikaitkan dengan menggunakan pendekatan normatif dan pendekatan yuridis, apakah lebih mengarah pada timbulnya kemaslahatan dalam kehidupan rumah tangga mereka atau sebaliknya.

\section{Metode Penelitian}

Jenis penelitian yang digunakan dalam penelitian ini adalah penelitian Kepustakaan (library research), yaitu metode penelitian yang digunakan untuk mencari data dengan membaca dan menelaah sumber tertulis yang menjadi bahan dalam penyusunan dan pembahasan dengan penelitian pustaka, datadata dari buku-buku, makalah-makalah ilmiah dan artikel yang selaras dengan objek penelitian. Adapun yang menjadi sumber data utama (primer) dalam penelitian ini adalah hasil penetapan Majelis Hakim Pengadilan Agama Lamongan dalam perkara wali adhal Nomor : 0073/Pdt.P/2008/PA.Lmg.

Pertimbangan Hakim dalam Penetapan Permohonan Wali Adhal Nomor : 0073/Pdt.P/2008/PA.Lmg. di Pengadilan Agama Lamongan.

Sesuai dengan pemaparan perkara wali adhal yang telah penulis jelaskan dalam pembahasan sebelumnya, bahwa pertimbangan hakim 
dalam penetapan Nomor: 0073/Pdt.P/2008/PA.Lmg. adalah permohonan pemohon dikabulkan oleh Majelis Hakim karena alasan tersebut tidak bertentangan dengan Hukum Islam dan Peraturan Perundang-undangan.

Ayah kandung pemohon sebagai wali yang berhak menikahkan pemohon dengan calon suaminya tidak dapat didengar keterangannya karena wali tidak pernah hadir dipersidangan, meskipun telah dipanggil secara resmi dan patut serta ketidakhadirannya tanpa alasan yang sah, maka Majelis Hakim berpendapat, wali pemohon adalah nyata-nyata seorang wali yang enggan menikahkan anaknya (adhal).

Pertimbangan hakim lainnya adalah, terhadap alat-alat bukti yang diajukan pemohon dalam persidangan tersebut. Saksi-saksi, surat dan bukti-bukti yang diajukan pemohon, dibuat oleh pejabat yang berwenang, telah bermaterai cukup, oleh karena itu surat-surat tersebut dapat digunakan sebagai alat bukti yang sah.

Majelis hakim juga mempertimbangkan, bahwa selain itu juga telah ditemukan fakta bahwa orang tua (ayah) pemohon tidak mau menikahkan pemohon dengan calon suaminya karena alasan ayah pemohon mempunyai pilihan lain. Oleh karena itu, hakim mempertimbangkan dengan memperhatikan ketentuan Pasal 18 ayat (5) Peraturan Menteri RI Nomor 11 Tahun 2007 Tentang Pencatatan Nikah, dihubungkan dengan Pasal 23 ayat (2) Kompilasi Hukum Islam. Maka wali nikah pemohon tersebut dapat dinyatakan sebagai wali adhal untuk menjadi wali dalam pernikahan pemohon dengan calon suaminya tersebut. Dan sesuai ketentuan Pasal 18 ayat (4) Peraturan Menteri Agama RI Nomor 11 Tahun 2007 tersebut, maka dengan sendirinya yang menjadi wali nikah pemohon adalah wali hakim.

Pertimbangan selanjutnya, bahwa berdasarkan pertimbanganpertimbangan tersebut diatas, maka Majelis Hakim berpendapat bahwa permohonan pemohon dapat dikabulkan. Sedangkan dalam mengabulkan permohonan pemohon, pertimbangan Majelis terletak pada bukti-bukti yang diajukan oleh pemohon. Berdasarkan bukti P.1, P.2 yang berupa surat penolakan dari kepala KUA Kecamatan Mantup Kabupaten Lamongan dan foto copy Kartu Keluarga (KK) atas nama wali pemohon selaku Kepala Keluarga dan pemohon selaku anggota keluarga yang dikeluarkan oleh Camat Mantup Kabupaten Lamongan telah bermaterai cukup, dan telah cocok dengan aslinya isi bukti tersebut menjelaskan mengenai tempat tinggal pemohon dan wali pemohon, sehingga bukti 
tersebut telah memenuhi syarat formal dan materiil serta mempunyai kekuatan yang sempurna dan mengikat.

Pertimbangan selanjutnya adalah syarat-syarat pemohon untuk melaksanakan pernikahan telah terpenuhi kecuali syarat wali pemohon adhal (enggan), kemudian keinginan pemohon untuk menikah juga telah mendapat penolakan dari Kantor Urusan Agama (KUA) Kecamatan Mantup Kabupaten Lamongan.

Majelis Hakim berpendapat bahwa alasan wali pemohon tersebut bukan alasan yang berdasarkan hukum. Pemohon dengan calon suami pemohon juga telah memenuhi syarat-syarat perkawinan sebagaimana diatur dalam Undang-Undang Nomor 1 Tahun 1974 Tentang Perkawinan dan Kompilasi Hukum Islam (KHI).

Analisis Pertimbangan Hakim Terhadap Penetapan Permohonan Wali Adhal dalam Teori Maqasid Al-Syari'ah dan Peraturan Perundangundangan.

Penetapan adalah keputusan pengadilan atas perkara permohonan (volunter), misalnya penetapan dalam perkara dispensasi nikah, izin nikah, wali adhal, poligami, perwalian, itsbat nikah, dan sebagainya. Penetapan merupakan jurisdiction valuntaria yang berarti bukan peradilan yang sesungguhnya karena pada penetapan hanya ada pemohon tidak ada lawan hukum. Didalam penetapan, Hakim tidak menggunakan kata "mengadili", namun cukup dengan menggunakan kata "menetapkan".

Pelaksanaan permohonan penetapan wali adhal yang dilakukan oleh Pengadilan Agama Lamongan ini sangat bermanfaat, disamping penyelesaian permasalahan wali nasab yang tidak mau menjadi wali nikah anak perempuannya juga dapat memberikan pemahaman kepada masyarakat tentang pentingnya wali nasab dalam pernikahan.

Dalam hal kasus permohonan penetapan wali adhal yang dilakukan oleh Pengadilan Agama Lamongan ini termasuk dalam hifzh al-nasl yang merupakan salah satu metode penerapan maqasid al-syari'ah, yang penerapannya ini ditekankan kepada manfaatnya dan meniadakan madharatnya. Sesuatu yang tidak ada nash hukumnya dalam Al-Qur'an maupun hadits, yang baik menurut akal. Dengan pertimbangan dapat mewujudkan kebaikan dan menghindari keburukan. Sesuatu yang baik menurut akal sehat maka pada hakikatnya tidak bertentangan dengan tujuan syara' secara umum. 
Jika dilihat berdasarkan maqasid al-syari'ah permohonan penetapan wali adhal yang dilakukan oleh Pengadilan Agama Lamongan termasuk hifzh al-nasl terkait dengan kasus wali adhal di Pengadilan Agama Lamongan kepada wali yang menolak menjadi wali dalam pernikahan anak perempuannya ini. Wali yang dimaksud dalam kasus di atas adalah wali nasab (ayah) yang menolak untuk menjadi wali dalam pernikahan anak perempuannya karena menganggap calon suami dari anaknya ini tidak seperti apa yang diinginkan oleh wali. Bahwasanya dengan adanya permohonan penetapan wali adhal ini dipandang baik oleh akal dan sesuai dalam syara' Islam.

Dilihat dari tingkatan daruriyyat kehidupan manusia itu memiliki lima prinsip yaitu, memelihara agama, memelihara jiwa, memelihara akal, memelihara keturunan, memelihara harta. Jika di fokuskan dari memelihara keturunan atau hifzh al-nasl wali hakim itu mengandung manfaat, karena jika pemohon dan calon suami pemohon tidak segera di nikahkan maka akan terjadi kejadian yang tidak diinginkan dan dikhawatirkan melakukan perbuatan yang dilarang syari'at Islam, misalnya zina, kawin lari, atau bunuh diri apabila pernikahan tidak segera dilangsungkan. Maka dari itu adanya dikabulkannya permohonan tersebut karena hakim mempertimbangkan kepada manfaatnya dan meniadakan madharatnya dalam pengambilan keputusan disetiap permasalahan. Dengan pertimbangan tersebut dapat mewujudkan kebaikan dan menghindari keburukan.

Sedangkan apabila dilihat dari segi tingkatan hajiyyah, yang dimana termasuk dalam pernikahan ini seperti ditetapkannya ketentuan adanya wali hakim pada saat akad nikah. Dan jika dikaitkan dengan pembahasan skripsi ini, permohonan wali adhal yang dilakukan oleh pemohon merupakan suatu jalan tengah dimana seorang wali yang tidak mau mewalikan anak perempuannya.

Dilihat dari akal sehat sebagai hifzh al-nasl yang hakiki dan telah sejalan dengan tujuan syara' yang telah ada, baik dalam bentuk nash AlQur'an dan Sunnah, maupun ijma' ulama terdahulu. Jika dikaitkan dengan kasus wali adhal yang dilakukan oleh Pengadilan Agama Lamongan bahwa adanya permohonan penetapan wali adhal yang dilakukan untuk mendapatkan izin menikah dengan menggunakan wali hakim ini dianggap sudah memenuhi syarat. Karena yang dinilai akal sehat sebagai hifzh al-nasl (memelihara keturunan) yang hakiki betulbetul sejalan dengan maksud dan tujuan syara', yaitu mewujudkan kemaslahatan bagi umat manusia, dan permohonan penetapan wali adhal yang dilakukan oleh Pengadilan Agama Lamongan.

Perkawinan dalam tata hukum Indonesia, khususnya bagi yang pemeluk agama Islam mewajibkan adanya wali dalam perkawinan. Kewajiban tersebut dapat dilihat dalam aturan yang dikeluarkan oleh 
pemerintah, antara lain dalam Kompilasi Hukum Islam dan Peraturan Menteri Agama Nomor 11 Tahun 2007 tentang Pencatatan Nikah. Keharusan adanya wali dalam perkawinan pada dasarnya merupakan kesepakatan mayoritas ulama, kecuali madzhab Hanafi yang tidak mensyaratkan wali bagi perempuan, apabila jika perempuan tersebut telah dewasa dan mampu mempertanggungjawabkan setiap perkataan dan perbuatannya.

Wali nikah menurut mayoritas ulama' maupun dalam peraturan perundang-undangan di Indonesia merupakan sesuatu yang harus ada. Karena wali nikah merupakan keharusan, maka konsekuensi dari tidak adanya wali adalah nikah tersebut dihukumi tidak sah. Meskipun para ulama' berbeda pendapat tentang kedudukan wali tersebut, apakah wali harus hadir dalam profesi akad nikah ataukah wali hanya diperlakukan ijinnya.

Sesuai dengan perkara wali adhal bahwa hakim mempertimbangkan wali yang berhak menikahkan perempuan tersebut tidak suka dengan calon suaminya. Dasar hukum yang digunakan hakim adalah Pasal 18 ayat (4) Peraturan Menteri Agama RI Nomor 11 Tahun 2007 tersebut, maka dengan sendirinya yang menjadi wali nikah pemohon adalah wali hakim.

Dalam kasus ini seorang wanita atau bakal calon mempelai wanita berhadapan dengan kehendak walinya yang berbeda, termasuk pilihan seorang laki-laki yang hendak dijadikan mantu (suami) wali menolak kehadirannya, karena wali tidak suka terhadap calon mempelai laki-laki.

Menurut penulis, pertimbangan hakim dalam penetapan perkara Nomor : 0073/Pdt.P/2008/PA.Lmg. dapat dibenarkan. Adapun yang menjadi dasar yang dapat mendukung kebenaran tersebut, dalam QS. AnNuur (24) ayat 32, yang artinya:

“Dan nikahkanlah orang-orang yang masih membujang di antara kamu, dan juga orang-orang yang layak (menikah) dari hamba-hamba sahayamu yang laki-laki dan perempuan. Jika mereka miskin, Allah akan memberi kemampuan kepada mereka dengan karunia-Nya. Dan Allah Maha Luas (pemberiannya), Maha Mengetahui". ${ }^{8}$

Ayat tersebut menunjukkan bahwa anjuran menikah bagi orang-orang yang sendiri atau wanita yang tidak mempunyai suami, baik perawan atau janda, dan laki-laki yang tidak mempunyai istri, hali ini berlaku untuk laki-laki dan perempuan yang merdeka (dan orang-orang yang layak kawin) yakni orang yang mukmin baik yang laki-laki maupun perempuan. Jika mereka miskin Allah akan memampukan mereka, berkat adanya perkawinan itu Allah akan memberi rezeki yang luas kepada

${ }^{8}$ Q.S. an-Nuur (24):32 
makhluknya.

Alasan ketidaksenangan wali terhadap calon mempelai laki-laki seringkali tidak, karena dalam permohonan tersebut, alasan ketidaksenangannya seringkali tidak jelas, dan bahkan hanya didasari oleh konflik emosional semata.

Kemudian penetapan Nomor : 0073/Pdt.P/2008/PA.Lmg. Majelis Hakim dalam penetapan perkara tersebut dengan pertimbangan bahwa wali pemohon tidak dapat didengar keterangannya karena tidak pernah hadir di persidangan meskipun telah dipanggil dengan sepatutnya. Berdasarkan keterangan para saksi yang menyatakan bahwa pada intinya pemohon berstatus perawan dan calon suaminya berstatus jejaka. Calon suami pemohon telah mempunyai pekerjaan tetap dan punya penghasilan yang cukup. Calon suami pemohon telah melamar pemohon, akan tetapi wali pemohon tidak bersedia menjadi wali karena alasan ayah pemohon mempunyai pilihan lain.

Dalam kasus tersebut, wali pemohon tidak bersedia menjadi wali karena wali mempunyai pilihan lain dan calon suami pemohon tidak seperti yang diinginkan wali. Pada dasarnya wali tidak ingin anak perempuannya salah dalam memilih suami, oleh karena itu seorang wali harus berhati-hati dalam mencarikan jodoh untuk anaknya, demi kehormatan dan kemuliaannya, serta seorang wali berhak menikahkan wanita yang dibawah perwaliannya jika calon suami pilihannya jelek akhlaknya, sebab orang yang baik beragama dan berakhlak akan memperlakukan istrinya dengan baik atau akan melepaskannya dengan baik.

Penetapan bahwa seorang wali telah adhal harus didasarkan pada pertimbangan yang sesuai dengan syari'at. Adapun jika wali menghalangi karena alasan yang sesuai dengan syari'at, seperti laki-lakinya tidak sekufu', atau maharnya kurang dari mahar mitsil, ada peminang lain yang lebih sesuai dengan derajatnya, maka dalam keadaan seperti ini perwalian tidak pindah ke tangan orang lain, karena ia tidaklah dianggap menghalangi (adhal).

Peraturan Menteri Agama Nomor 30 Tahun 2005 tentang Wali Hakim ${ }^{9}$. Dalam peraturan ini, disebutkan bahwa adhalnya wali merupakan salah satu syarat atau keadaan dibolehkannya wali hakim sebagai wali dalam perkawinan calon mempelai perempuan dengan calon

${ }_{9}$ Peraturan Menteri Agama Nomor 30 Tahun 2005 tentang Wali Hakim 
mempelai laki-laki. Untuk menyatakan adhalnya seorang wali, maka diperlukan penetapan dari Pengadilan Agama yang mewilayahi tempat tinggal calon mempelai wanita. Peraturan Menteri Agama Nomor 11 Tahun 2007 tentang Pencatatan Nikah. Ketentuan mengenai wali adhal dalam peraturan ini sama dengan ketentuan dalam peraturan tahun $2005^{10}$.

\section{Penutup}

Pertimbangan hakim menurut maqasid al-syariecah bahwa dalam permohonan penetapan wali adhal tidak hanya termasuk dalam hifzh alnasl tetapi juga dalam hifzh al-din;

1. Pertimbangan hakim dalam hifzh al-nasl adalah karena hakim mempertimbangkan dengan adanya wali menghalangi pemohon untuk melangsungkan pernikahan dengan laki-laki yang sekufu akan menghalangi/mempersulit juga untuk mendapatkan keturunan yang baik dan juga dikhawatirkan melakukan tindakan yang dilarang oleh

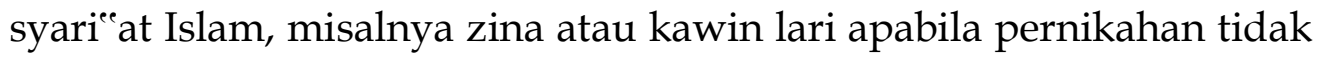
segera dilangsungkan.

2. Wali adhal dalam hifzh al-din yaitu karena hakim mempertimbangkan bahwa memelihara dan melaksanakan kewajiban keagamaan dalam menikah akan menjunjung tinggi martabat manusia sekaligus menyempurnakan pelaksanaan kewajibannya kepada Tuhan. Sedangkan berdasarkan Peraturan Perundangundangan bahwa ayah pemohon tidak suka dengan calon suami pemohon yaitu berdasarkan Pasal 18 ayat (4) Peraturan Menteri Agama RI Nomor 11 Tahun 2007 dan dalam Pasal 19 Kompilasi Hukum Islam disebutkan bahwa wali nikah merupakan rukun yang harus dipenuhi bagi calon mempelai wanita, karena tidak sah menikah tanpa wali. Walaupun seorang wali mempunyai hak untuk memilihkan calon suami bagi anaknya, wali dilarang mempersulit perkawinan wanita yang berada dalam perwaliannya selama mendapatkan calon yang sekufu. Apabila seorang wali menolak untuk menikahkan wanita yang berada dalam perwaliannya, maka disebut sebagai wali adhal (keberatan). Maka menetapkan seorang wali itu adhal atau tidak harus didasarkan pada pertimbangan yang matang. Dengan demikian, penetapan tersebut tidak hanya

10 Peraturan Menteri Agama Nomor 11 Tahun 2007 tentang Pencatatan Nikah 
menciptakan kepastian hukum, tetapi juga kemanfaatan dan keadilan sebagai cita-cita hukum tertinggi.

\section{Daftar Pustaka}

Penetapan Pengadilan Agama Lamongan perkara permohonan wali adhal nomor : 0073/Pdt.P/2008/PA.Lmg.

Himpunan Peraturan Perundang-undangan Yang Berkaitan Dengan Kompilasi Hukum Islam Dengan Pengertian Dalam Pembahasanya, Perpustakaan Mahkamah Agung RI, 2011.

Peraturan Menteri Agama Nomor 11 Tahun 2007 tentang Pencatatan Nikah

Peraturan Menteri Agama Nomor 30 Tahun 2005 tentang Wali Hakim

Abu Dawud. Sunan Abi Dawud; "kitab al-Nikah". Bab al-Walt. Beirut: Dar al-Fikr,t.t.,II: 229, hadits no. 2085.

Al-Hafidh Bin Hajar Al-'Asqalani, “Bulugh Al-Maram”. Surabaya: Nurul Huda.

Hasbi Umar. Nalar Fiqih Kontemporer. Jakarta: Gaung Persada Press, 2007.

Muhammad Jawad Mughniyah. "Fiqh Lima Mdzhab, Ja'fari, Hanafi, Maliki, Syafi'i, Hambali". Jakarta: Lentera, 1996.

Syaikh al-'Allamah Muhammad bin 'Abdurrahman ad-Dimasyqi. Fiqih Empat Mazhab. Bandung. Hasyimi, 2015. 